\title{
BIAS GENDER DALAM MASYARAKAT MUSLIM: ANTARA AJARAN ISLAM DENGAN TRADISI TEMPATAN
}

\author{
Mohd Anuar Ramli*
}

\begin{abstract}
The issue of gender bias into polemics among Muslim scholars. This scenario triggered by the view that blames the feminist epistemology of religious and traditional male dominated society patriarchy in Islam as a factor in the occurrence of gender bias against women. Therefore, this article will discuss how Islam came with the release of her policy, the supply of a number of rights and responsibilities appropriate to the existence of a caliph or a slave. In addition, there are several factors that cause gender injustice against women, whether internal in nature such as the interpretation of religious tradition or external, such as the community. Finally, a number of issues of gender bias that occurs in the Muslim community made to assess whether the practice is based on the resolution of the Qur'an and the Prophet SAW pattern by al-Sunnah, or traditions they are based on the community (Tribal Tradition).
\end{abstract}

Keywords: gender, feminist, tradition, patriarchy, Muslim society

Lecturer at Department of Fiqh and Usul, Academy of Islamic Studies, University Malaya 


\section{PENDAHULUAN}

Kebiasaannya, istilah gender dihuraikan sebagai perbezaan antara lelaki dan perempuan hasil daripada konstruksi sosio-budaya. Dengan kata lain, ia merujuk kepada sifat maskulin (masculinity) dan feminin (femininity) yang dipengaruhi dengan kebudayaan, simbolik, stereotaip dan pengenalan diri. ${ }^{1}$ Walaupun pada dasarnya gender membincangkan tentang lelaki dan perempuan tetapi perbincangan banyak difokuskan kepada perempuan. Menurut Ursula King, senario ini disebabkan golongan perempuan telah lama dipinggirkan dalam sejarah dan budaya masyarakat. ${ }^{2}$

Perempuan adalah makhluk mysterium fascinosum. Mereka penuh misteri, kurang difahami dan sering disalahtafsirkan. Dalam Islam, perempuan merupakan salah satu subjek yang mendapat perhatian serius. Misalnya, dalam al-Qur'an sendiri terdapat perbincangan berbagai masalah keperempuanan dalam lebih 10 surah, di antaranya dua surah yang terkenal iaitu surah alNisā' (al-Nisā' al-Kubrā) dan surah al-Ṭalāq (al-Nisā' al-Ṣughrā). Selain itu, masalah keperempuanan turut ditampilkan dalam surah al-Baqarah, al-Mā'idah, al-Nūr, al-Aḥzāb, al-Mumtaḥanah dan al-Tahrīm. Di samping itu perkataan perempuan juga disebut sebanyak 100 kali dalam dua puluh surah. Dalam hadis-hadis Rasulullah S.A.W. juga terdapat huraian yang begitu banyak sekali tentang perempuan ini. Sehingga boleh dikatakan, dalam bab apa sahaja, wujud hadis tentang perempuan.

Antara persoalan yang menjadi perbincangan dalam wacana gender adalah isu bias gender dalam masyarakat Islam. Isu ini banyak berhubung kait dengan ketidakadilan terhadap perempuan. Seringkali ajaran keagamaan ataupun Syariat Islam sebagai punca kepada segala ketidakadilan atau diskriminasi terhadap perempuan, sedangkan secara praktikalnya, suatu amalan ataupun tradisi masyarakat kadangkala tidak selari dengan ajaran Islam yang ideal.

\footnotetext{
1 Raymond J. Corsini (1999), The Dictionary of Psychology. Philadelphia: Psychology Press, h. 405.

2 Ursula King (1995), "Introduction: Gender and Study of Religion" dalam Ursula King (ed.), Religion and Gender. Oxford UK: Blackwell Publishers, h. 1.
} 
Dalam interaksi Syariat Islam dengan adat atau budaya masyarakat setempat, terdapat berbagai-bagai pendekatan yang diaplikasi. Antaranya, mengiktiraf amalan budaya yang baik, menolak amalan budaya yang fasid, memperbaiki amalan budaya masyarakat setempat dan sebagainya. Dalam interaksi ini, golongan ulama terutamanya mubaligh awal banyak berkompromi dengan adat dan tradisi tempatan. Hasil interaksi ini, lahir kepelbagaian budaya Islam berdasarkan realiti setempat yang mana corak dan pola hubungan gender juga berbeza antara satu masyarakat dengan masyarakat yang lain.

\section{KEDUDUKAN PEREMPUAN DALAM MASYARAKAT MUSLIM}

Golongan perempuan biasanya digambarkan sebagai kumpulan yang tertindas dalam masyarakat, sama ada di Barat atau Timur, agama Ibrahim (Abrahamic Religions) sama ada Yahudi, Kristian mahupun Islam, malah dalam agama budaya yang lain seperti Hindu dan Buddha. ${ }^{3}$

Dalam sejarah kemanusiaan yang panjang, kaum perempuan mengalami nasib tragis yang mana mereka dilayan sebagai barangan dan alat pemuas nafsu kaum lelaki. Mereka ditindas dan tidak dihormati kemanusiaannya, malah dipinggirkan dengan alasan tradisi dan adat istiadat. ${ }^{4}$ Dalam peradaban kuno serta masyarakat primitif, mereka ditindas tanpa perikemanusiaan dan tidak diberi layanan yang adil. ${ }^{5}$ Masyarakat Sumeria dan Yunani menganggap kaum perempuan sebagai sejumlah pemilikan kaum lelaki. ${ }^{6}$ Masyarakat Cina membunuh anak perempuan kerana

3 Arvind Sharma (ed.), (1987), Women in World Religions. New York: State University of New York Press.

4 Fatima Umar Nasif (2001), Women in Islam: A Discourse in Rights and Obligations. (terj.) Burhan Wirasubrata \& Kundan D. Nuryakien, Menggugat Sejarah Perempuan: Mewujudkan Idealisme Gender Sesuai Tuntutan Islam. Jakarta: Penerbit Cendekia, h. 17.

5 Jasni Sulong (2006), "Kedudukan Wanita dalam Pembahagian Pusaka", Jurnal Syariah. Akademi Pengajian Islam, Universiti Malaya, bil. 14 (2), h. 125.

6 As'ad al-Sahmaranī (1997), al-Mar'ah fì al-Tārīkh wa al-Syarī'ah. c. 3, Beirut: Dār al-Nafā'is, hh. 20-30. 
bebanan kepada keluarga, masyarakat India membakar hiduphidup perempuan bersama mayat suami, ${ }^{7}$ masyarakat Arab praIslam menanam anak perempuan hidup-hidup ${ }^{8}$ khususnya Banī Asad dan Ban̄̄ Tamīm di samping menganggap perempuan sebagai sejumlah pemilikan yang boleh diwarisi. ${ }^{10}$

Menurut Nikki R. Kiddie, kebanyakan pengkaji Barat yang tidak pakar dalam kajian kawasan (terutamanya Asia Barat) akan menokok tambah sisi negatif pola hubungan gender di dunia Islam dan digambarkan perempuan Islam sebagai mangsa (victim) kepada masyarakat lelaki. ${ }^{11}$ Gambaran yang diberikan menunjukkan Islam sebagai agama yang menindas kaum perempuan. ${ }^{12}$ Salah faham ini dapat ditanggap dalam kajian dan pandangan sarjana Barat yang ethnocentric (eurocentrism). Ia dapat dilihat dalam pandangan mereka yang menggambarkan perempuan yang menjalankan tugas domestik sebagai ibu adalah penindasan, perempuan yang menutup aurat dan berhijab dipandang sebagai pemisahan sosial dan perempuan yang dikahwini dengan sah (poligami) dipandang sebagai pelecehan seksual. ${ }^{13}$ Selain itu, antara gambaran lain:

7 Fatima Umar Nasif (2001), op.cit., hh. 17 \& 24.

8 Al-Qur'ān al-Karīm, al-Naḥl (16): 58-59. Lihat juga Reuben Levy (1969), The Social Structure of Islam. e. 2, Cambridge: Cambridge University Press, h. 91.

9 Hasan Ibrahim Hasan (1979), Tārīkh al-Islāmī al-Siyāsī wa al-

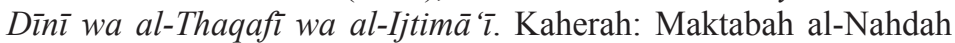
al-Misriyyah, j. 1, h. 65.

10 W. Robertson Smith (1903), Kinship and Marriage in Early Arabia. London: Adam \& Charles Black, h. 92.

11 Nikki R. Keddie (2007), Women in the Middle East: Past and Present. New Jersey, USA: Princeton University Press, h. 10.

12 Robert Spencer \& Phyllis Chesler (2007), The Violent Opression of Women in Islam. Los Angeles: David Horowitz Freedom Center, hh. 6-7.

13 Anne Sofie Roald (2001), Women in Islam: The Western Experience. London: Routledge, hh. 109-110. Lihat juga beberapa salah faham tentang kedudukan perempuan dalam Kamar Ainiah Kamarulzaman (1986), "The Legal Status of Women in Islam: With Special Reference to the Islamic Family Law in West Malaysia", (Thesis $\mathrm{Ph} . \mathrm{D}$, University of Kent at Canterbury, England, unpublished), h. 23. 
a) Perempuan disubordinasi dan tidak mempunyai hak yang lebih baik berbanding masyarakat silam. Pandangan ini turut disokong oleh golongan feminis Arab awal, khususnya Leila Ahmad. Beliau berpendapat perempuan sebelum Islam mempunyai kedudukan yang lebih baik dalam masyarakat egalitarian. $^{14}$

b) Perempuan dalam Islam mempunyai kedudukan yang lebih baik tetapi masih ada unsur penindasan dan ketidakadilan dalam ajaran Islam terutamanya dalam aspek perkahwinan, penceraian, kesaksian dan pewarisan. Contohnya pandangan John Esposito. ${ }^{15}$

c) Perempuan dalam Islam langsung tidak mempunyai kedudukan yang baik, malah disubordinasi, dipinggirkan dan dipencilkan. Islam diberikan gambaran yang buruk. ${ }^{16}$

d) Budaya Islam sama ada yang diekspresikan dengan verbal atau visual merupakan dalam bentuk kekerasan, dominasi, distorsi dan sikap yang meremehkan. Pandangan kolonial dan orientalis sejajar dengan kritikan feminis ${ }^{17}$ seperti Mernissi tentang harem sebagai sebuah lembaga seksual yang diskriminatif. ${ }^{18}$ Sebagai contoh Malek Alloula (1986) dalam karyanya The Colonial Harem, menggambarkan keadaan harem sebagai ketiadaan batas khayalan kenikmatan seksual, amalan lesbian dan pesta yang penuh dengan hiburan (carnivalesque orgy). ${ }^{19}$

14 Leila Ahmad (1992), Women and Gender in Islam. New Haven: Yale University Press, hh. 41-44.

15 John L. Esposito (2002), What Everyone Needs to Know about Islam. New York: Oxford University Press, hh. 142-146.

16 Lihat Herbert L. Bodman (1998), "Introduction", dalam Herbert L. Bodman \& Nayereh Esfahlani Tohidi (eds.), Women in Muslim Societies: Diversity within Unity. London: Lynne Rienner Publishers, hh. 1-10.

17 Fatima Mernissi (1975), Beyond the Veil: Male-Female Dynamics in a Modern Muslim Society. New York: J. Wiley.

18 Fātimah al-Mirnissī (1997), Ahlām al-Nisā' al-Harīm: Hikāyāt Tafūlah fì al-Harìm. Damsyik: Dār Ward li al-Ṭibā'ah wa al-Nasyr wa al-Tawzī'.

19 Fadwa El Guindi (1999), Veil: Modesty, Privacy, and Resistance. Oxford, UK: Berg Publishers, h. 23. 
Hakikatnya, pada zaman Rasulullah S.A.W., kaum perempuan memperolehi hak-hak yang dinafikan sepanjang sejarah kemanusiaan. ${ }^{20}$ Pendekatan Rasulullah selaras dengan doktrin egalitarianisme dan keistimewaan ini dinikmati kaum perempuan dalam Islam.

\section{REKAYASA KEDUDUKAN PEREMPUAN DALAM ISLAM}

Islam datang dalam keadaan masyarakat Arab yang Jahiliah mempunyai tahap kebejatan sosial yang tinggi. Kaum perempuan tidak mempunyai kedudukan yang baik dalam strata masyarakat. Islam telah mengangkat martabat kaum perempuan dan memberikan hak-hak tertentu kepada mereka. Daripada tidak mempunyai sebarang hak, kaum perempuan mendapat kebebasan hak kehartaan melalui pewarisan dengan nisbah perempuan lelaki $1: 2,{ }^{21}$ daripada tidak mempunyai hak untuk hidup dan bertransaksi, kaum perempuan mendapat kebebasan hak hidup dan kesaksian dengan nisbah kaum perempuan lelaki 2:1,22 begitu juga dalam hak perkahwinan, daripada mengalami pelecehan seksual tanpa batasan, kaum perempuan mendapat hak kebebasan dan kemuliaan maruah dengan nisbah perempuan lelaki 4:1. ${ }^{23}$ Justeru melalui penurunan al-Qur'an secara beransur-ansur dalam tempoh 23 tahun telah berjaya membebaskan perempuan daripada belenggu penindasan.

Sehubungan dengan itu, lelaki dan perempuan mempunyai hak dan tanggung jawab yang sama dalam aspek ibadat (hubungan manusia dengan Allah) seperti dalam taklifan solat, puasa, zakat dan haji. Hal yang sama juga berlaku dalam mu'amalat (hubungan manusia sesama manusia), misalnya hak memiliki dan mewarisi

20 Sayyid Muhammad Șiddīq Hassan Khān al-Qanūjī al-Bukhārī (1981), Husn al-Uswah bimā Thabata min Allāh wa Rasūlihi fi alNiswah. c. 2, Beirut: Mu'assasah al-Risālah.

21 Al-Qur'ān al-Karīm, al-Nisā' (4): 11.

22 Al-Qur'ān al-Karīm, al-Baqarah (2): 282.

23 Al-Qur'ān al-Karīm, al-Nisā' (4): 3. 
harta dan bertransaksi. ${ }^{24}$ Dalam menjamin persamaan status kemanusiaan, Islam turut membahagikan tugasan dan tanggung jawab antara lelaki dan perempuan selaras dengan perbezaan fisiologi mereka. Perbezaan antara kualiti dan kapasiti ini bukan berkaitan dengan superioriti atau inferioriti. ${ }^{25}$ Ia tidak menimbulkan ketidakadilan gender selagi mana hubungan kemanusiaan masih berada dalam koridor keagamaan. Ini kerana kelebihan hak tertentu, diimbangi dengan penambahan kewajipan yang khusus.

\section{FAKTOR BIAS GENDER DALAM MASYARAKAT MUSLIM}

Dalam wacana gender, terdapat beberapa faktor yang menyebabkan berlakunya hubungan gender yang tidak adil dalam masyarakat. Menurut Siti Musdah Mulia, terdapat tiga faktor utama yang menyebabkan ketidakadilan gender khususnya terhadap perempuan, iaitu pertama dominasi budaya patriaki. Seluruh elemen pembentuk kebudayaan memiliki watak yang memihak kepada atau didominasi kepentingan lelaki. Kedua, interpretasi ajaran agama sangat didominasi pandangan yang bias gender dan bias patriaki. Ketiga, hegemoni negara yang begitu dominan. Selaras dengan itu, beliau menyarankan agar dilakukan counter ideology dan counter hegemony. ${ }^{26}$

Pengaruh lokal terutamanya kebudayaan memainkan peranan yang penting dalam proses interaksi dengan Syariat Islam yang egalitarian. Peralihan pusat kuasa dari Hijjaz ke kawasan yang masih kuat dengan fahaman patriaki mengubah dan mengurangkan hak-hak kaum perempuan dalam masyarakat. Pusat pemerintahan Khulafa' al-Rasyidin pada asalnya terletak di ibu kota Madinah al-Munawarrah, telah digantikan oleh Dinasti Umawiyyah ke

24 Ibrāhīm Madkūr (t.t.), Fī al-Fikr al-Islāmī. Kaherah: Samirco li al-Ṭibā'ah wa al-Nasyr, h. 163; Muhammad Quṭb (1992), Syubhāt Hawl al-Islām. c. 21, Kaherah: Dār al-Syurūq, h. 114.

25 Maulana Wahiduddin Khan (2000), Women: Between Islam and Western Society. (terj.) Farida Khanam, New Delhi: Goodword Press, h. 148.

26 Siti Musdah Mulia (2007), Islam dan Inspirasi Kesetaraan Gender. Yogyakarta: Kibar Press, hh. 58-59. 
ibukota Damsyik, dan kemudian diubah oleh Dinasti 'Abbasiyyah ke ibukota Baghdad. ${ }^{27}$

Dengan itu, dunia Islam mengalami enkulturasi dengan mengadopsi budaya-budaya androcentrism (berpusat pada kepentingan lelaki). Wilayah Islam bertambah luas ke bekas wilayah jajahan Parsi di timur, bekas jajahan Rom dengan pengaruh kebudayaan Yunaninya di barat, dan ke Afrika, seperti Mesir dengan sisa-sisa kebudayaan Mesir kunonya di bahagian selatan. Pusat-pusat kebudayaan tua tersebut memperlakukan kaum perempuan sebagai the second $\operatorname{sex}^{28}$

Selain berinteraksi dengan tamadun yang berasaskan fahaman patriaki, perkembangan teknologi penulisan dan percetakan pada zaman Dinasti 'Abbasiyyah menyumbang kepada pengukuhan fahaman patriaki dalam masyarakat Islam. Proses pembukuan (tadwin) yang lebih sistematik terhadap karya hadis, fiqh dan sebagainya telah menyebabkan berlakunya unifikasi dan kodifikasi teks-teks ajaran Islam. Secara tidak langsung pemikiran para ulama setempat yang berlatarkan suasana semasa dan setempat khususnya fahaman patriaki dikatakan mendapat keabsahan dan mengalami pembakuan. ${ }^{29}$

Kemudiannya, teks tersebut diwariskan kepada generasi demi generasi. Ia diterima dengan nilai yang sakral (suci) dan tidak dapat diganggu-gugat walaupun berlaku perubahan sosio-budaya, sedangkan fiqh tidak dapat dipisahkan dari nilai kemanusiaan. Fenomena pensakralan pemikiran keagamaan (taqdīs al-afkār al-diniyyah) ini seolah menyamakan nilai fiqh dengan Syariah. Sedangkan Syariah bersumberkan wahyu ketuhanan, bernilai tetap (absolute), transenden dan abadi (eternalistic).

27 Nasaruddin Umar (2001), Argumen Kesetaraan Gender Perspektif al-Qur'an. c. 2, Jakarta: Paramadina, h. 308.

28 Nasaruddin Umar (2002), "Metode Penelitian Berperspektif Gender Tentang Literatur Islam" dalam Siti Ruhaini Dzuhayatin et al., Rekonstruksi Metodologis Wacana Kesetaraan Gender Dalam Islam. Yogyakarta: Pustaka Pelajar, hh. 197-198.

29 Nasaruddin Umar (2002), "Teologi Pembebasan Perempuan" dalam Luthfi Assyaukanie (ed.), Wajah Liberal Islam di Indonesia. Jakarta: JIL, h. 45. 
Selain faktor-faktor tersebut, fenomena diskriminasi gender ini dikatakan berasal dari doktrin keagamaan sama ada dalam agama Samawi atau agama Budaya, terutamanya melibatkan "teologi penciptaan perempuan" (nafs wāhidah) dan "drama kosmis" (penyingkiran Adam dan Hawa dari syurga) atau "original sin". Ia diabsahkan oleh agama-agama Samawi seperti Yahudi, Kristian dan Islam. Menurut golongan feminis, faktor ini menjadi titik tolak terhadap ketidakadilan dalam hubungan di antara lelaki dan perempuan. Justeru, sumber-sumber Isrā 'ìliyyāt atau mitos tersebut mempengaruhi sebahagian besar ulama klasik terutamanya dalam persepsi mereka terhadap kaum perempuan.

Antara ayat al-Qur'an yang menyatakan tentang penciptaan perempuan pertama ${ }^{30}$ adalah firman Allah S.W.T. dalam surah alNisā' yang bermaksud:

Wahai sekalian manusia, bertakwalah kepada Tuhanmu yang Telah menciptakan kamu dari seorang diri, dan dari padanya Allah menciptakan isterinya; dan daripada keduanya Allah memperkembang biakkan lelaki dan perempuan yang banyak.

$$
\text { Al-Nisa' (4): } 1
$$

Dalam huraian penciptaan perempuan pertama dalam Islam, terdapat dua pandangan utama dalam kalangan mufassirin. Majoriti ulama klasik berpendapat perempuan diciptakan daripada tulang rusuk Adam a.s. Dengan kata lain, penciptaan perempuan berasal dari jenis yang satu iaitu Adam, dan tidak sama elemen penciptaannya dengan lelaki. Antara kalangan ulama klasik termasuklah antaranya al-Tabari, ${ }^{31}$ al-Zamakhsyari, ${ }^{32}$

30 Terdapat 3 ayat al-Qur'an yang berkaitan dengan penciptaan perempuan, iaitu al-Nisā' (4): 1, al-A'rāf (7): 189 dan al-Zumar (39): 6.

31 Abū Ja'far Muḥammad b. Jarīr al-Ṭabarī (2001), Jāmi ' al-Bayān 'an Ta'wāl Āyi al-Qur'ān. Kaherah: Dār Hajr, juz. 6, h. 341.

32 Jār Allāh Abī al-Qāsim Maḥmūd b. 'Umar al-Zamakhsyarī (1998), al-Kasysyäf. Riyadh: Maktabah al-'Abikan, juz. 2, h. 5. 
Ibn Kathir, ${ }^{33}$ al-Alusi, ${ }^{34}$ al-Qurtubi, ${ }^{35}$, al-Suyuti, ${ }^{36}$ dan kalangan ulama kontemporari seperti al-Buti, ${ }^{37}$ dan Hamka. ${ }^{38}$ Begitu juga dalam tafsir Bahasa Melayu terbitan BAHEIS, kaum perempuan ditafsirkan penciptaannya daripada rusuk Adam. ${ }^{39}$

Pandangan jumhur mufassir ini disokong oleh beberapa hadis Nabi S.A.W. yang secara literalnya menggambarkan penciptaan tersebut. Di antaranya sabda Nabi S.A.W.: ${ }^{40}$

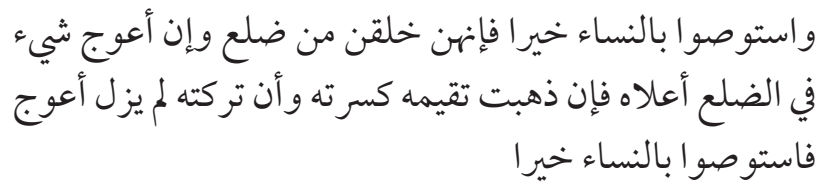

Berwasiatlah kepada paraperempuan. Sesungguhnya perempuan itu diciptakan dari tulang rusuk yang bengkok, dan tulang rusuk yang paling bengkok adalah tulang rusuk yang ada paling atas, jika kamu ingin meluruskannya, maka kamu akan mematahkannya, dan jika kamu biarkan, maka tulang rusuk itu tetap bengkok, maka berwasiatlah kepada para perempuan dengan kebaikan

Walaupun begitu, terdapat kumpulan minoriti dari kalangan ulama klasik dan kontemporari yang berpendapat, perempuan

33 'Imād al-Dīn Abī al-Fidā’ Ismā'îl b. Kathīr (t.t.), Tafsīr al-Qur'ān al- 'Azìim. Mesir: Mu'assasah Qurțubah, j. 3, h. 333.

34 Syihāb al-Dīn al-Sayyid Mạ̣mūd al-Alūsī (t.t.), Rūḥ al-Ma'ānī. Beirut: Dār Ihyyā' al-Turāth al-'Arabī, juz. 4, h. 209.

35 Abū 'Abd Allāh Muhammad b. Aḥmad b. Abī Bakr al-Qurțubī (2006), al-Jāmi 'li Ahkē̄m al-Qur'ān. Beirut: Mu'assasah al-Risālah, j. 6 , h. 6 .

36 Jalāl al-Dīn al-Suyūțī (2003), al-Durr al-Manthūr fì Tafsìr bi alMa 'thūr. Kaherah: Dār Hajr, juz. 4, h. 209.

37 Muhammad Sa 'īd Ramaḍān al-Būṭī (1993), al-Islām Malāz Kull al-Mujtama 'āt al-Insān: Limāzā wa Kayfa?. Beirut: Dār al-Fikr alMu'āṣir, hh. 111-112.

38 Hamka (1987), Tafsir al-Azhar. Jakarta: Pustaka Panjimas, j. 1, h. 174.

39 Sheikh Abdullah Basmeih (t.t.), Tafsir Pimpinan Ar-Rahman Kepada Pengertian al-Qur'an. Kuala Lumpur: Darulfikir, h. 178.

40 Al-Bukhārī, Șaḥịh al-Bukhārī, "Bāb al-Wușāt bi al-Nisā'”, no. hadis: 4890. 
pertama tidak diciptakan dari tulang rusuk Adam, sebaliknya dari substansi atau unsur yang sama. Di antara ulama klasik adalah Abu Muslim. ${ }^{41}$ Manakala dalam kalangan ulama kontemporari ialah Muhammad 'Abduh dan Rasyid Rida, ${ }^{42}$ Hasbi Ash-Shiddieqy ${ }^{43}$ dan Quraish Shihab. ${ }^{44}$

Golongankeduamenyatakan bahawahadis yangmemperihalkan penciptaan perempuan dari tulang rusuk tersebut perlu dihuraikan secara metaforis, bukan literal. Ini kerana ia akan memberi kesan terhadap tafsiran dan kefahaman hukum Islam. Menurut Rasyid Rida, pemahaman ini berkait dengan pengaruh penceritaan Bible. Sekiranya tiada kisah seumpamanya dalam Bible, pasti tiada tafsiran mengenai penciptaan perempuan daripada rusuk lelaki.

Walaupun tafsiran al-Qur'an bersifat polisemik, pengkaji mendapati daripada kedua-dua pihak, hujah dan tafsiran jumhur mufassirin adalah lebih tepat, kerana metodologi yang digunapakai adalah berasaskan tafsìr bi al-ma thūr iaitu tafsīr al-Qur'ān bi alSunnah, iaitu antara tafsiran yang berautoriti. Ini kerana penciptaan Hawa daripada tulang rusuk Adam adalah bukti kekuasaan Allah S.W.T., bukan simbol inferioriti perempuan.

Sebaliknya, pandangan yang menyatakan penciptaan Hawa dari tulang rusuk Adam menyebabkan kerendahan darjat perempuan adalah berasal dari pemikiran Barat. ${ }^{45}$ Walaupun dalam Bible jelas menceritakan kronologi proses penciptaan tersebut, mereka tidak percaya dan tidak menerima Bible sebagai wahyu tuhan, sebaliknya dianggap sebagai kata-kata lelaki yang berbaur patriaki. Selaras dengan itu, ia perlu dinilai secara kritikal menggunakan

${ }^{41} \quad$ Abū Muslim al-Așfihānī al-Khawalan̄̄, Namanya Ya'qūb b. 'Awf. Salah seorang Tabi'in yang thiqah. Abū Hassan 'Ali b. 'Umar alDaruqutni (1985), Dhikr Asmā' al-Tābi 'īn. Beirut: Mu'assasah alKutub al-Thaqāfiyyah, h. 280.

42 Muḥammad 'Abduh \& Muhammad Rasyīd Riḍā (1367H), Tafsīr alManār. c. 3, Mesir: Dār al-Manār, juz. 4, hh. 331-332.

43 Muhammad Hasbi Ash-Shiddieqy (1995), Tafsir al-Qur'anul Majid An-Nur. Semarang: Pustaka Rizki Putra, j. 1, h. 752.

44 Muhammad Quraish Shihab (2001), Tafsir al-Mishbah. Jakarta: Lantera Hati, vol. 2, h. 314.

45 Gerda Lerner (1986), The Creation of Patriarchy. New York: Oxford University Press, h. 183. 
pendekatan hermeneutik dan didekonstruksi pengungkapan (articulation) patriaki tersebut. ${ }^{46}$

Selain itu, pentafsiran "al-qiwāmah" dalam surah al-Nisā' turut menjadi titik tolak kepada wujudnya elemen bias gender persoalan hukum. Firman Allah S.W.T. yang bermaksud:

Kaum lelaki itu adalah pemimpin dan pengawal yang bertanggungjawab terhadap kaum perempuan, oleh kerana Allah telah melebihkan sebahagian mereka (lelaki) atas sebahagian yang lain (perempuan), dan kerana mereka (lelaki) telah memberi nafkah sebahagian dari harta mereka.

$$
\text { al-Nisa' (4): } 34
$$

Kebanyakan mufassir seperti al-Ṭabarī dan al-Rāzī mentafsirkan kepimpinan ini disebabkan kekuatan akal lelaki dan kesempurnaan fizikalnya. Oleh sebab itu, tugas khalifah, imam solat, kewajipan jihad, azan, saksi, wali nikah, talak, rujuk dan had empat orang jumlah isteri diberikan kepada lelaki. ${ }^{47}$ Pandangan ini diterima oleh mufassir kontemporari seperti 'Abduh dan Riḍa ${ }^{48}$ serta Syeikh Nawawi al-Bantani. ${ }^{49}$ Ini kerana kaum lelaki dianggap lebih baik dari perempuan. ${ }^{50}$ Mereka disifatkan sebagai golongan yang kuat fizikal, tidak beremosi, tajam akal dan dengan karakter tersebut mereka mempunyai kelebihan ke atas orang perempuan, khususnya sebagai pemimpin. Selaras dengan itu, golongan lelaki mendapat hak istimewa berbanding perempuan. Senario ini secara langsung memberi kesan terhadap huraian fiqh. Misalnya, mereka mempunyai kuasa sebagai ketua keluarga, mendapat hak wilayah, hak warisan 2:1, hak kesaksian 1:2 dan berbagai lagi ketetapan

46 Elisabeth Schüssler Fiorenza (1994), "Bread Not Stone: The Challenge of Feminist Biblical Interpretation" dalam Sneja Gunew (ed.), A Reader in Feminist Knowledge. c. 3, New York: Routledge, h. 264.

47 Al-Ṭabarī (2001), op.cit., juz. 6, h. 687; al-Rāzī (t.t.), op.cit., juz. 10, hh. 90-91.

48 'Abduh \& Rị̣ā (1947), op.cit., juz. 5, hh. 67-70.

49 Muḥammad Nawawī al-Jāwī (1960), Marah Labīd. Kaherah: Dar Ihyā̄' al-Kutub al-'Arabiyyah, h. 149.

$50 \quad$ Ibn Kathīr (t.t.), op.cit., j. 4, h. 20. 
hukum yang melebihkan lelaki dan membezakan mereka dari golongan perempuan. ${ }^{51}$ Sedangkan menurut al-Ghazzālī, alqiwämah ini tidak memberi makna penguasaan (al-qahr) ke atas perempuan. ${ }^{52}$ Menurut Mạ̣mūd Syaltūt, kelebihan ini bukan menjadi asas perhambaan dan diskriminasi kaum perempuan, sebaliknya ia merupakan kelebihan tanggung jawab mencari nafkah untuk memenuhi keperluan rumah tangga. ${ }^{53}$

Begitu juga Sunnah Nabi S.A.W., terdapat juga beberapa hadis yang menjadi faktor timbulnya bias gender dalam masyarakat Islam. Di antaranya, hadis tentang larangan kepimpinan perempuan. Sabda Nabi S.A.W.: ${ }^{54}$

$$
\text { لن يُفلح قوم ولّو أمرهم امرأة }
$$

Tidak akan berjaya selama-lamanya sesuatu bangsa yang melantik perempuan memegang urusan mereka

Berasaskan hadis tersebut, sebahagian ulama menjadikan ia sebagai asas kepada larangan kepimpinan perempuan yang meliputi semua bentuk kepimpinan. Walau bagaimanapun, hadis tersebut dipertikaikan keautoritiannya oleh golongan kedua. ${ }^{55}$ Ini kerana:

${ }_{51} \quad$ Al-Zamakhsyarī (1998), op.cit., juz. 2, h. 67.

52 Muhammad al-Ghazzālī (t.t.), Qaḍ̂yā al-Mar'ah: Bayna al-Taqūlīd al-Rākidah wa al-Wāfidah. Mesir: Dār al-Syurūq, h. 154.

53 Mahmud Syaltut (2004), Tafsìr al-Qur'ān al-Karimm. c. 12, Kaherah: Dār al-Syurūq, h. 141.

54 Muḥammad b. Ismā'il al-Bukhārī (1987), Șaḥịh al-Bukhārī. c. 3, Beirut : Dār Ibn Kathīr, Kitāb al-Maghāzī, no. hadis 4163, juz. 4, h. 1610. Lihat juga; Muhammad b. 'Alī al-Syawkānī (1961), Nayl alAwțār Syarh Muntaqa al-Akhbār min Ahādīth Sayyid al-Akhyār. c. 3, Kaherah : Maktabah wa Mațba 'ah Muștafā al-Ḥalabī, juz. 8, h. 273; Abū 'Īsā Muhammad b. 'Īsā b. Sawrah al-Tirmidhī (t.t.), Al-Jāmi ' al-Ṣahīh wa huwa Sunan al-Tirmidhī. Beirut : Dār Ihyyā' al-Turāth al-'Arabī, Kitāb al-Fitan, no. hadis 2262, juz. 4, h. 527.

55 Hibah Ra'ūf 'Izzat (1997), Al-Mar'ah wa al- 'Amal al-Siyāsī : Ru'yah Islāmiyyah. (terj.) Bahruddin Fannani, Penglibatan Wanita Dalam Politik Mengikut Perspektif Islam. Kuala Lumpur : The International Institute of Islamic Thought, h. 100. 
i. Perawi hadis (Abū Bakrah) tersebut hanya mengutarakan hadis tersebut selepas 25 tahun beliau dengar daripada Nabi SAW iaitu semasa Perang Jamal yang diketuai Aisyah. Hadis ini dikemukakan selepas beliau tidak mahu terlibat dalam Perang Jamal. ${ }^{56}$

ii. Matan hadis khusus kepada Maharaja Persia dan kerajaan Kisra yang melantik anak perempuannya. ${ }^{57}$ Hadis tersebut adalah menjawab persoalan yang dikemukakan oleh para Sahabat tentang tindakan Raja Parsi, Busyrawayh b. Abruwiz b. Hurmuz yang melantik anak perempuannya, Buran untuk menggantikannya sebagai Maharaja Parsi. Tujuan di sebalik hadis ini adalah untuk memperkecil-kecilkan kerajaan Parsi dan tiada kaitan dengan kepemimpinan dalam Islam. Walaupun adanya kaedah usul "pengambilkiraan hukum berdasarkan lafaz umum bukannya sebab khusus", dalam kes ini ia bersifat khusus.

iii. Bertentangan dengan nas al-Quran. Al-Quran telah memerihalkan kisah Ratu Saba' dengan jelas. ${ }^{58}$ Ratu Balqis seorang pemimpin yang bijak, berfikiran luas, demokratis dan mengutamakan kesejahteraan rakyat baginda.

iv. Hadis tersebut adalah hadis $\bar{A} h \bar{a} d$. Secara sebulat suara para ulama menyatakan bahawa hadis $\bar{A} h \bar{a} d$ hanya menghasilkan hukum yang zannī sekalipun perawinya Imam al-Bukhari, seorang imam hadis yang besar.

Selain hadis larangan kepimpinan tersebut, terdapat hadis lain yang turut menggambarkan inferioriti kaum perempuan iaitu hadis yang secara jelas menegaskan bahawa perempuan adalah golongan yang lemah akal. Sabda Nabi S.A.W.: ${ }^{59}$

56 Fatima Mernisi telah melakukan double investigation sama ada secara pensejarahan atau metodologi terhadap perawi hadis Abū Bakrah. Untuk maklumat lanjut, lihat Fatima Mernissi (1991), Women and Islam: An Historical and Theological Enquiry. (terj.) Mary Jo Lakeland, Cambridge : Blackwell, h. 49.

57 Aḥmad b. 'Alī b. Ḥajr al-'Asqalānī (1379), Fath al-Bārī. Beirut : Dār al-Ma'rifah, juz. 13, h. 56.

58 Al-Qur'ān, al-Naml (27) : 23.

59 Al-Bukhārī (1987), Șah̄̄h al-Bukhārī. Kitāb al-Ḥayd, no. hadis 298, juz. 1, h. 116; al-Tirmidhī (t.t.), Sunan al-Tirmidhī. Kitāb al-Īmān, no. hadis 2613 , juz. 5 , h. 10 . 


$$
\text { ما رأيت من ناقصات عقل ودين أذهب للب الرجل الحازم من }
$$

Aku tidak pernah melihat perempuan-perempuan yang kurang akal dan agamanya dapat meluluhkan hati lelaki yang perkasa dari salah seorang dari kalian.

Secara tekstualnya, hadis tersebut menyatakan perempuan sebagai golongan yang lemah akal, sedangkan dari aspek kontekstual, ia tidak mengesahkan kelemahan akal dan agama kaum perempuan. Menurut Muḥammad 'Imārah, ia tidak mengilustrasikan ciri khusus seorang perempuan, malah tidak mensyariatkan syariat yang tetap dan tidak juga mutlak mengenai perempuan. Sebaliknya ia menggambarkan realiti semasa yang mana boleh berubah dan berkembang selaras dengan perubahan zaman. Selain itu, dalam riwayat lain yang senada, ia bermaksud keadaan-keadaan khusus bagi perempuan yang memiliki sifat tertentu yang mana ia boleh menyebabkan mereka dimasukkan ke dalam neraka, ${ }^{60}$ bukan disebabkan mereka seorang perempuan. ${ }^{61}$ Ini kerana:

i. Perempuan lebih dahulu memeluk Islam berbanding lelaki kerana dorongan akal seperti Ummu Habībah terlebih dahulu dari bapanya Abū Sufyān, Fāṭimah dahulu dari saudaranya 'Umar al-Khaț̣āb dan lain-lain. ${ }^{62}$

ii. Kekurangan akal tersebut kesan penafian hak pendidikan perempuan pra-Islam. Justeru Islam mengasaskan demokrasi

60 Sifat mazmumah ini tidak terkecuali pada golongan lelaki. Untuk maklumat mengenai perkara-perkara yang boleh menyebabkan perempuan masuk neraka dapat dilihat dalam Muhammad alȘāyim (t.t.), Kabā'ir wa Dhunūb al-Nisā'. Kaherah: Maktabah alTawfïqiyyah, h.

61 Muḥammad 'Imārah (2002), al-Taḥrīr al-Islāmī li al-Mar'ah. Kaherah: Dār al-Syurūq, hh. 88-89.

62 Abdel-Hamid Eliwa (2001), The Early Muslim Women. Mansourah: Dar al-Manarah, h. 66; Asmā' Muḥammad Ziyādah (2001), Dawr alMar'ah al-Siyāsì fì 'Ahd al-Nabì wa al-Khulafā' al-Rāsyidīn. (terj.) Kathur Suhardi, Peran Politik Wanita Dalam Sejarah Islam. Jakarta: Pustaka al-Kautsar, h. 11. 
pendidikan tanpa melihat kepada jantina. Dengan peluang pendidikan yang ada, kaum perempuan dapat menyamai dan mengatasi kemampuan mental kaum lelaki.

iii. Kekurangan agama merujuk kepada biologi perempuan yang mempunyai kitaran haid, nifas dan sebagainya. Ini kerana kaum perempuan tidak wajib mendirikan solat dan puasa ketika waktu tersebut. ${ }^{63}$ Dalam masa yang sama, Islam tidak merendahkan perempuan yang sedang mengalaminya. Justeru kekurangan tersebut adalah berhubungkait dengan kekurangan dalam ibadah tertentu. ${ }^{64}$

Justeru, dalam menilai asas hubungan gender yang dilihat mendiskriminasikan kaum perempuan, para peneliti perlu mengambilkira latar belakang budaya dan tradisi asal bagi masyarakat terbabit, bukannya secara melulu menyalahkan ajaran Islam. Selain itu, penilaian yang dilakukan tidak perlu terikut-ikut dengan rentak feminis Barat yang standpoints without footings. Sejajar dengan itu, pandangan mereka terhadap Islam terbatas pada tingkatan realiti sosial, sedangkan interpretasi ulama khususnya terhadap hak-hak perempuan tidak bersifat homogen sebaliknya bervariasi, begitu juga implementasi ajaran agama dalam masyarakat Islam. Walaupun al-Quran dan al-Sunnah merupakan sumber utama kehidupan masyarakat Islam, namun dalam realiti implementasinya dalam masyarakat memperlihatkan kepelbagaian, malah wujud elemen sinkretisme yang berbeza dari amalan masyarakat Madinah yang ideal. ${ }^{65}$

63 Muḥammad Sa 'īd Ramaḍān al-Būṭ̂i (2008), al-Mar'ah Bayn Ṭughyān al-Niz̄ām al-Gharbī wa Lațà 'if al-Tasyrī' al-Rabbānī. Damsyik: Dar al-Fikr, h. 178.

64 Zaitunah Subhan (1999), Tafsir Kebencian : Studi Bias Gender Dalam al-Qur'an. Yogyakarta : LkiS, h. 62.

65 Rasulullah S.A.W. membina masyarakat Islam yang ideal di Madinah dengan penghapusan adat dan tradisi jahiliyyah yang menindas kaum perempuan dan memperkenalkan syariat Islam yang membebaskan. Ia diterapkan secara beransur-ansur hingga lahirnya sebuah model masyarakat unggul. Lihat Akram Diyā' al-'Umari (1983), al-Mujtama' al-Madanī fì 'Ahd al-Nubuwwah: Khașā'iṣuh wa Tanżimuh al-Ūlā. Madinah al-Munawwarah: Maktabah al'Arabiyyah al-Su'ūdiyyah, hh. 71-79. 


\section{ISU-ISU BIAS GENDER DALAM MASYARAKAT MUSLIM}

Gagasan pembebasan yang dijana oleh Islam telah berjaya mengangkat kedudukan perempuan dalam masyarakat Muslim. Namun, untuk mendakwa ajaran Islam diamalkan sepenuhnya dalam lapisan masyarakat Muslim mungkin dilihat agak longgar, kerana tradisi asal tetap mencorakkan pola hubungan lelaki dan perempuan dalam masyarakat. Amalan ini kadang kala mewarnai wajah keislaman yang bervariasi selaras dengan perbezaan masyarakat.

Proses adaptasi Syariat Islam dengan keragaman budaya dan masyarakat setempat mewarnai khazanah perbendaharaan hukum Islam. Proses sosialisasi ajaran Islam berhadapan dengan amalan tradisi dan budaya setempat menimbulkan pelbagai bentuk hubungan gender yang baik dalam masyarakat Islam. Ada yang dilihat mempunyai hubungan yang baik seperti masyarakat zon Melayu, ada yang hubungan kurang baik seperti zon Arab dan ada yang tidak baik seperti di zon anak benua India.

Masyarakat Islam di kebanyakan kawasan, khususnya dalam aspek hubungan kekeluargaan dan kehartaan, masih kuat mengamalkan adat dan tradisi lama. Terdapat hubungan yang kuat antara subordinasi perempuan dalam dunia Islam dengan tradisi dan budaya setempat. ${ }^{66}$ Dalam sesetengah masyarakat Muslim di benua India, janda tidak dibenarkan kahwin lagi. Di Punjab dan Uttar Pradesh (India), perempuan Muslim tidak boleh mewarisi harta, dalam kalangan masyarakat Mappila di Malabar (Kerala, India), sistem pewarisan berasaskan peraturan matrilineal diamalkan. ${ }^{67}$ Sebahagian daripada amalan adat lain yang menimbulkan kekerasan terhadap perempuan adalah

\footnotetext{
66 V.A. Mohamad Ashrof (2005), Islam and Gender Justice: Questions at the Interface. Delhi: Kalpaz Publications, h. 263.

Ibid., h. 261.
} 
pembunuhan maruah (honour crimes) di Timur Tengah, ${ }^{68}$ tradisi karo kari di Pakistan, ${ }^{69}$ khitan anak perempuan yang melampau di negara Afrika seperti Sudan dan Mesir, ujian dara, dowry death atau dowry murderer ${ }^{70}$ juga di India. Manakala di Arab Saudi, perempuan tidak dibenarkan mengundi, memandu kereta, mempamerkan wajah atau bercakap dengan lelaki bukan mahram di khalayak ramai. ${ }^{71}$ Selain itu, dalam masyarakat kontemporari, lahir bentuk hubungan gender yang tidak mesra, contohnya dalam rumahtangga sering berlaku keganasan, penderaan fizikal dan mental, pemukulan, pembunuhan, pemerkosaan dan pelecehan seksual.

Selaras dengan keadaan sosio-budaya masyarakat Muslim yang dilihat tidak lagi berlandaskan panduan Nabi S.A.W., lahirnya golongan yang ingin membebaskan golongan yang tertindas di dalam masyarakat. Fenomena ini menjadi momentum kepada perjuangan feminisme yang mana kebanyakan golongan feminis sama ada lelaki atau perempuan lahir dari masyarakat yang tertindas, khususnya dari Timur Tengah dan kawasan IndoPakistan.

Dalam perbincangan fiqh yang lebih luas juga, terdapat sejumlah perbezaan hukum antara lelaki dan perempuan. ${ }^{72}$ Bagi sesetengah pengkaji, perbezaan ini menggambarkan ketidakadilan

68 "Honor Killing in a Cross-Cultural Context" dalam Unni Wikan (2008), In Honor of Fadime: Murder and Shame. (terj.) Anna Paterson, edisi revisi, Chicago, Illinois: University of Chicago Press, h. 70; Suad Joseph et al. (eds.) (2005), Encyclopedia of Women \& Islamic Cultures: Family, Law, and Politics. vol. II, Leiden: Brill, hh. 221-227.

69 Iftikhar Haider Malik (2005), Culture and Customs of Pakistan. Connecticut: Greenwood Press, hh. 145 \& 149.

70 Bukan saja diamalkan oleh masyarakat Hindu tapi segelintir Muslim. Lihat Veena Talwar Oldenburg (2002), Dowry Murder: The Imperial Origins of a Cultural Crime. New York, USA: Oxford University Press, h. 222; Ranjana Kumari (1989), Brides Are Not for Burning: Dowry Victims in India. New Delhi: Radiant.

71 Ibid., h. 262.

72 Sa'd b. Syāri' b. 'Iwaḍ al-Harbī (1415), al-Aḥkām allatī Tukhāliff fìhā al-Mar'ah al-Rajul. Riyāḍ: Dār al-Muslim; Șābir 'Abd al-Raḥmān Ța'īmah (2007), al-Mar'ah al-Muslimah: Bayna Gharā'iz al-Basyar wa Hidāyah al-Islām. Riyadh: Maktabah al-Rusyd, hh. 165-168. 
gender kerana menempatkan kedudukan perempuan yang tidak sejajar dengan lelaki (bias gender). ${ }^{73}$ Selaras dengan perbezaanperbezaan hukum di antara lelaki dan perempuan tersebut, adakah Islam tidak menjamin kesetaraan gender dan melebihkan kaum lelaki daripada perempuan? Dan adakah kaum perempuan benarbenar mengalami bias gender? Ataupun ketidakadilan itu adalah hasil salah faham dalam menilai kedudukan lelaki dan perempuan dalam Islam. Dengan kata lain, ketidakadilan tersebut bukan sebahagian ajaran keagamaan, sebaliknya tradisi masyarakat setempat atau pun ia adalah amalan yang menyimpang (deviant) dari syariat Islam dan budaya tempatan.

Menjawab persoalan ini, al-Qaradawi menegaskan perbezaan di antara lelaki dan perempuan dalam sesetengah hukum tidak bermakna jenis lelaki lebih mulia dan lebih hampir kedudukannya di sisi Allah SWT daripada jenis perempuan. Sebaliknya perbezaan ini berkehendakkan tugas dan tanggungjawab yang sesuai dengan fitrah setiap lelaki dan perempuan. ${ }^{74}$ Sesungguhnya manusia yang paling mulia di sisiNya adalah mereka yang paling bertaqwa sama ada seorang lelaki atau perempuan.

Justeru, untuk menyalahkan ajaran Islam sepenuhnya dalam ketimpangan hubungan gender dalam masyarakat Muslim adalah tidak wajar. Ini kerana pengaruh tradisi tempatan yang mengakar umbi dalam masyarakat Muslim tidak merefleksikan ajaran Islam yang sebenar sebagaimana keteladanan Nabi SAW yang mesraperempuan.

\section{KESIMPULAN}

Dalam masyarakat muslim, tidak semua amalan yang bias gender berasaskan faktor keagamaan, sebaliknya terdapat beberapa amalan atau perbuatan yang berasaskan asas yang bervariasi. Secara khususnya, terdapat beberapa bentuk amalan, iaitu:

73 Khoiruddin Nasution (2002), Fazlur Rahman Tentang Wanita. Yogyakarta: Academia, h. 83.

74 Nașr Salmān \& Su'ād Suṭ̣̄ī (eds.), Fatāwāa al-Nisā' li Aṣhāa alFad̄ilah Yūsuf al-Qaradāwīi, wa Mahmūd Syaltūt, wa 'Abd al-Halīm Maḥmūd, wa Muhammad Mutawallī Sya 'rāwē wa Ahmmad Hamānī. Beirut: Mu’assasah al-Risālah, hh. 574-577. 
1. Amalan yang berorientasikan ajaran Islam yang benar, iaitu menurut panduan al-Quran dan al-Sunnah. Contohnya menghormati perempuan sebagai ibu, isteri, anak dan saudara.

2. Amalan yang berorientasikan ajaran Islam yang disalahtafsir, iaitu misalnya al-qiwāmah sebagai dominator bukan protector, serta perempuan tidak boleh memimpin. Kesannya berlaku pemingitan perempuan dan domestifikasi mereka dalam ruang rumah tangga sahaja.

3. Amalan yang berorientasikan tradisi yang baik ('urf șahīh). Misalnya, 'amal ahl al-Madinah dikira sebagai sumber hukum bagi Imam Mālik. Ini kerana Madinah merupakan pusat interpretasi al-Quran dan implementasi al-Sunnah. Contoh lain adalah seperti mengambil kira sumbangan perempuan dalam rumah tangga yang mana lahirnya konsep Harta Sepencarian, Perpantangan dan sebagainya.

4. Amalan yang berorientasikan tradisi yang tidak baik (tribal tradition/ 'urf fāsid). Misalnya amalan sistem kasta yang menebal khususnya dalam menentukan pasangan rumah tangga, pembayaran mas kahwin oleh perempuan dan amalan khitan firaun dalam kalangan anak perempuan.

5. Amalan yang menyimpang dari ajaran Islam dan tradisi masyarakat (deviant behavior and practice). Misalnya pembunuhan maruah (saudara perempuan atau anak perempuan), pengabaian nafkah isteri sama ada zahir atau batin tanpa alasan munasabah, penderaan pasangan perempuan sama ada fizikal atau mental.

Sehubungan dengan itu, para pengkaji perlu jelas dalam menilai isu-isu bias gender dalam masyarakat Islam sama ada amalan itu benar-benar bersumberkan ajaran Islam yang sahih, ataupun ianya kesalahfahaman dalam mentafsirkan ajaran tersebut, atau amalan itu bersumberkan tradisi masyarakat setempat ('urf șaḥihh) ataupun amalan tersebut menyimpang (deviant) dari nilai dan norma keagamaan serta tradisi masyarakat yang murni (tribal tradition). Contohnya dalam isu memukul isteri atau keganasan rumahtangga, tiada kaitan dengan hak suami ketika isteri nusyuz, sebaliknya tindakan itu jelas terpesong (deviant) dari ajaran Islam yang murni dan tradisi masyarakat yang baik. 
Syariat Islam yang bersifat universal dapat menangani kepelbagaian ragam budaya dengan menerima tradisi yang baik, menolak tradisi buruk dan menapis tradisi yang samar dalam masyarakat. Walau bagaimanapun, tidak semua tradisi yang berakar umbi dalam masyarakat Muslim dapat dikikis sepenuhnya. Ini berikutan latar belakang tradisi dan peradaban silam masih kukuh di dalam warisan masyarakat. Hakikatnya, peradaban silam sama ada bersumberkan peradaban Yunani, Byzantine, India Kuno dan sebagainya berasaskan tradisi patriaki. Tiada satu gambaran yang positif terutama dalam pola hubungan gender. Perempuan biasanya digambarkan sebagai simbol seksual, pemuas nafsu dan tertindas.

Justeru itu, Islam mengajar manusia untuk meraikan konsep keseimbangan, keserasian, keselarasan, keutuhan, bersikap baik sesama umat manusia tanpa mengira perbezaan gender, mahupun ras manusia. Konsep hubungan gender dalam Islam lebih dari sekadar mengatur keadilan gender dalam masyarakat, tetapi secara teologi dan teleologi mengatur pola hubungan mikrokosmos (manusia), makrokosmos (alam), dan Tuhan. Hanya dengan demikian manusia dapat menjalankan fungsinya sebagai khalifah yang adil dan hamba yang salih. 
Jurnal Fiqh, No. 7 (2010) 49-70 